This is a self-archived - parallel published version of this article in the publication archive of the University of Vaasa. It might differ from the original.

\title{
Determinants of equity changes in partial acquisitions of Finnish multinationals in foreign markets
}

Author(s): Oguji, Nnamdi; Owusu, Richard A.; Larimo, Jorma

Title: Determinants of equity changes in partial acquisitions of Finnish multinationals in foreign markets

Year: $\quad 2019$

Version: Publisher's PDF

Copyright C)2019 Emerald Publishing Limited. This manuscript version is made available under the Creative Commons AttributionNonCommercial 4.0 International (CC BY-NC 4.0) license, https://creativecommons.org/licenses/by-nc/4.0/

Please cite the original version:

Oguji, N., Owusu, R. A. \& Larimo, J., (2019). Determinants of equity changes in partial acquisitions of Finnish multinationals in foreign markets. Baltic journal of management 14(2), 268290. https://doi.org/10.1108/BJM-05-2018-0179 
BJM

14,2

\section{8}

Received 6 May 2018

Revised 19 August 2018

9 November 2018

3 December 2018

5 December 2018

Accepted 7 December 2018

\title{
Determinants of equity changes in partial acquisitions of Finnish multinationals in foreign markets
}

\author{
Nnamdi Oguji \\ Marketing Department, University of Vaasa, Vaasa, Finland \\ Richard Afriyie Owusu \\ Marketing Department, Linneuniversitet Ekonomihogskolan Vaxjo, \\ Vaxjo, Sweden, and \\ Jorma Larimo \\ Marketing Department, University of Vaasa, Vaasa, Finland
}

\begin{abstract}
Purpose - When entering foreign markets, multinationals can acquire part of a foreign firm and can increase or decrease their equity stake over time. However, extant studies have mainly focused on equity stake acquired during initial market entry. The paper aims to discuss this issue.

Design/methodology/approach - This study fills this gap by using the Uppsala model to analyze six cases of international acquisitions of Finnish multinationals in global markets.

Findings - The authors found that firms change their equity stake in partially acquired foreign subsidiaries: when they have learned about the host country and businesses of the partially acquired firms, when they have gained target-specific experience, when they build trust and ensure relationship commitment and finally, when they jointly develop and exploit opportunities.

Originality/value - This study is one of the first to apply the Uppsala model to empirically analyze international acquisitions, thus paving the way for behavioral and process-oriented approaches. The study contributes to knowledge of post-entry strategies of multinationals.
\end{abstract}

Keywords Equity changes, Internationalization process, Partial acquisition, Post-market entry,

Staged acquisition

Paper type Research paper

\section{Introduction}

The expansion of globalization in the last few decades has been accompanied by a significant increase in the number of acquisitions with an average yearly value of over $\$ 2$ trillion (UNCTAD, 2015). Acquisitions are said to have become the most important foreign direct investment vehicle for multinationals seeking foreign market entry (Brouthers and Dikova, 2010), and as a strategy for overcoming knowledge limitations and speedily establishing positions in foreign markets (Johanson and Vahlne, 2009). Nevertheless, foreign acquisitions face various challenges due to the need to integrate the new foreign subsidiary.

When entering foreign markets, multinationals have the option to acquire fully at the beginning or acquire partly and increase their level of equity over time. Full acquisition is an acquisition in which the acquiring firm takes 100 percent ownership of the target firm (Contractor et al., 2014). Partial acquisitions are takeover transactions where the acquiring firm has less than 100 percent ownership (Shahrur, 2005). Staged acquisition is an acquisition that requires an initial partial equity stake (i.e. a partial acquisition) with a contractual requirement to acquire the remaining equity over several years (Meyer and Tran, 2006; Oguji and Owusu, 2017).

While many international business (IB) studies have been concerned with how and why multinationals choose their entry mode at the time of market entry (e.g. Benito et al., 2009), the question of why multinationals increase or decrease their equity commitments over time

Vol. 14 Nonal of Manement Vol. 14 No. 2, 2019 pp. $268-290$

(C) Emerald Publishing Limited 1746-5265

DOI 10.1108/BJM-05-2018-0179 
after initial market entry in foreign acquisitions has gained limited attention. Extant studies related to this issue can be classified into three streams. First, there are studies that have accounted for changes in entry modes (e.g. Benito et al., 2009; Putzhammer et al., 2018) or, more specifically, why international joint ventures (IJVs) change to wholly owned subsidiaries (Puck et al., 2009; Song and Zeng 2015). Second, there are studies that imply that the reasons for changes in entry mode are differences in actual operations established at initial entry compared to the strategic intentions before entry (Santangelo and Meyer, 2011). Third, there are studies that focus on the effects of post-entry equity changes on aspects of performance (Magnusson, 2007; Ogasavara and Masiero, 2012). While all these streams provide some evidence of changes in entry modes and investigate the antecedents or results of equity changes in foreign subsidiaries, they do not account for entry mode changes in the context of acquisitions. As a result, they are all limited in explaining why MNEs change their equity stake in acquisitions after market entry.

The study by Puck et al. (2009) shows that IJVs are changed into wholly owned subsidiaries (WOS) as a result of: gaining local knowledge possessed by the foreign IJV partner, reduction in the level of perceived political, economic, social and legal uncertainty and the level of internal pressures faced in the IJV. Santangelo and Meyer (2011) suggest that unforeseen opportunities induce foreign investors with modest initial objectives to revise their strategic intentions after entry and, if favorable conditions emerge, increase their commitment. They found out that in the presence of institutional voids, investors are prone to invest in ex-ante information searches that enable them to reduce the likelihood of ex-post commitment decrease. Benito et al. (2009) re-conceptualized foreign operation mode as one consisting of mode packages in the form of mode continuation, within mode change, mode role change, mode additions and deletions and full mode change. Ogasavara and Masiero (2012) found that changes in equity of Japanese foreign subsidiaries in Brazil are aimed at improving their longevity.

While informative, these three streams of studies have the following limitations. First, the timing of increasing commitment decisions from IJVs to WOS is different from the timing of commitment decisions in acquisitions. The limited duration of IJVs makes the conversion from IJVs to WOS more evident than in acquisitions. Duration does not limit the decision to increase or decrease commitment decisions in acquisitions. Consequently, the circumstances, mechanisms and reasons leading to the change from IJV to WOS cannot be generalized for equity changes in international acquisitions. Second, whereas in acquisition there is the likelihood of unneeded assets or redundant resources due to the difficulty in separating desirable assets from undesirable assets (Das and Teng, 2000), in IJVs, assets are desirable assets and easily separable as both partners come to form the IJV with only the assets each desire (Hennart and Reddy, 1997). Consequently, the conversion from IJVs to WOS or the full acquisition of IJVs is less complex than the conversion of partially acquired targets to full acquisition due to difficulties in valuating assets when the assets of the target firm include non-desired assets that are not easily separable. Third, the study by Santangelo and Meyer (2011) focuses on all FDI projects and cannot be generalized to the acquisition context. Fourth, the study by Puck et al. (2009) and Magnusson (2007) assume that ownership is either whole or partial. Ownership in acquisition is, however, a continuum within a range of percentage ownership. Thus, it may not necessarily be a full acquisition and may not necessarily be divested completely. Fifth, the study by Benito et al. (2009) provides a holistic conceptualization that firms do change their entry modes in the foreign market. However, they did not specifically address the "how" and "why" questions and their study was not in the context of acquisitions. Finally, Ogasavara and Masiero (2012) showed that firms aim to increase their equity stake to improve the longevity of the acquired firm. However, they did not account for the determinants or mechanisms leading to equity changes of the foreign-acquired subsidiaries.

\section{Finnish multinationals in foreign markets}


BJM

14,2

We aim to analyze and deepen our understanding of equity changes in acquired foreign subsidiaries using internationalization process theory (Johanson and Vahlne, 1977, 2009). To do this, we integrate it with literature on international acquisitions and undertake empirical case studies of Finnish MNEs' acquisitions in foreign markets. Thus, the main contribution of our study is to develop propositions and a framework of equity changes in international acquisitions. We believe that while considerable IB research has focused on equity stake at entry, uncovering the later changes or continuum of changes will bring a process and behavioral approach to the study of acquisitions, which has previously been done mainly using cross-sectional and quantitative methods together with economic theories. This is a major contribution to the research on acquisitions. It opens a new area of research that will enable researchers to delve into the processes and managerial firm interactions that occur during the process from partial acquisitions to full acquisitions or divestment.

\section{Internationalization process model and foreign acquisition}

\subsection{Uppsala internationalization process model}

The internationalization process model or Uppsala model (Johanson and Vahlne, 1977, 2009) is rooted in organizational learning and resource dependence theory. The focus of our study is on the 2009 model. However, the 1977 model is referenced where necessary.

The two versions of the internationalization process model are shown in Figure 1. The 1977 model is shown in Figure 1(a) and the 2009 model is shown in Figure 1(b). The main difference between the 1977 model (Johanson and Vahlne, 1977) and 2009 version (Johanson and Vahlne, 2009) is the role of business networks in internationalization.

The core of the 2009 model, like the 1977 model, is the state and change variables and how they impact each other. The state variables refer to the current situation of internationalization from which the change variables are analyzed. In the 1977 model, psychic distance and the lack of knowledge about foreign markets led to a liability of foreignness. In the 2009 model, the main limitation is a liability of outsidership, i.e. lack of relevant relationships. The 2009 model is a dynamic process depicting how mutual

(a)

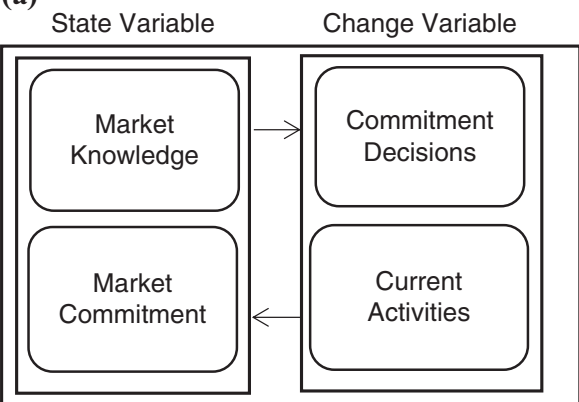

(b)

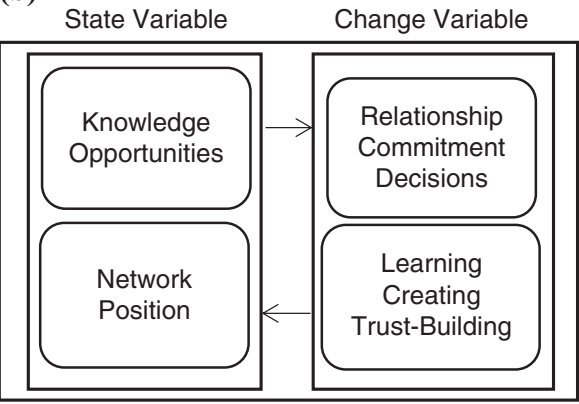

Figure 1.

Internationalization process model
Notes: (a) Basic mechanism of internationalization; (b) the business network internationalization process model

Source: Johanson and Vahlne $(1977,2009)$ 
relationships and commitment between a firm and its partners in business networks build up their knowledge and opportunities. The four variables in the 2009 model are network position, knowledge opportunities, relationship commitment decisions and learning and trust-building.

Scholars have used Johanson and Vahlne (1977) to argue that the choice of acquisition is a result of learning (e.g. Andersson et al., 1997; Lin et al., 2009). For example, the model of Andersson et al. (1997) depicts how firms undertake international acquisition through learning from a direct or indirect relationship with their business partners with or without a local presence. Other studies (e.g. Figueira-de-Lemos and Hadjikhani, 2014) have used the Uppsala model to show how firms increase or decrease their commitment in response to perceived beneficial or detrimental conditions. The foregoing studies have contributed to our understanding of different commitment decisions, such as divestment, wait-and-see, market-exit and re-entry.

The Uppsala model (1977) and studies, based on it referred to in the foregoing, have been criticized for being deterministic (Andersen, 1993). It has also been claimed that the model has a stage assumption and, therefore, cannot be used to explain the internationalization of born global firms and international acquisitions (Oviatt and McDougall, 2005). Johanson and Vahlne (2009) answered these criticisms by arguing that the Uppsala model does not specify the form that increased commitment might take because commitment decisions may increase or decrease depending on performance. Consequently, the model is by no means deterministic.

In this study, it is argued that the Uppsala model can be used to study international acquisitions on the assumption that an acquisition is much more likely to be successful if it is preceded by some previous relationship between the acquirer and the target firm (Johanson and Vahlne, 2009). Öberg (2014) found that the ability to learn about each other, gain knowledge about the business environment, develop trust and possibly establish new relationships with customers of the acquired firm is critical to success. Furthermore, for post-acquisition integration to go further, the parties must speedily learn about each other and develop trust after the acquisition (Holland and Salama, 2010). Consequently, acquisitions without a previous relationship with the target firm may result in conflicts and a likelihood of failure (Andersson et al., 1997). In addition, the advancement of the Uppsala model to one that takes into cognizance the role of business networks, trust and knowledge development in business relationships, addresses the criticisms previously leveled against it.

\subsection{Network position}

The Uppsala model emphasizes that the existing business relationships a firm occupies within its business network make up the network position of the firm. According to Johanson and Vahlne (2009), the network position makes it possible for the firm to identify and exploit opportunities, determine which geographical markets to enter and decide upon the corresponding entry mode to use to enter the market. It provides the firm with alliance learning, centrality (the extent to which a firm occupies a central position such that it has independent access to other network ties) and structural hole position (a firm's brokerage locations between two otherwise disconnected firms in the network) (Lin et al., 2009). Thus, a firm's network position is pivotal to how, when and where its internationalization process will start.

Partial acquisition can serve as existing relationships that form part of a firm's network position. Added to the fact that firms can have business relationships with a target firm before undergoing acquisitions, it can be argued that partial acquisition and target-specific experience (relationship-specific knowledge) can provide a platform (state variable) from which knowledge, trust or commitment to the firm-specific relationships develop, leading to 
a commitment decision. It can be increasing commitments such as increasing equity stake in the acquisition or decreasing equity commitments depending on the outcome of previous commitment decisions (Figueira-de-Lemos and Hadjikhani, 2014).

\subsection{Knowledge opportunities}

The 2009 model assumes that knowledge opportunities serve as the basis for relationship commitment decisions. Thus, the knowledge opportunities that are inherent in the firm's relationships with its partner firms initiate the process of learning, creating opportunities and building trust.

Full acquisition or increase in equity commitments can be seen as an outcome of knowledge opportunities or a consequence of trust-building and relationships the partners develop during their interaction in previous exchange relationships (e.g. partial acquisition, distributor relationships). It can also be seen as an opportunity that develops as a result of the interaction between partners who build knowledge together and come to trust each other as they commit themselves further to the relationship (Johanson and Vahlne, 2009). Opportunity development entails gradually and sequentially increasing recognition and exploitation of an opportunity in the existence of trust (Holm et al., 2015). The opportunity that develops from this relationship may be unilateral, with the parent firm learning about the target firm's needs, capabilities, markets and networks from an outsidership position (Johanson and Vahlne, 2009); bilateral, when two interacting firms identify an opportunity; or multilateral, when multiple firms identify an opportunity (Duarte and García-Canal, 2004). Conversely, in the absence of opportunity development, a firm might have no reasons to keep its ongoing relationship with the target firm. In the case of pre-existing partial or full acquisition, the relationship may get dissolved, and consequently, the parent MNE will divest their investments (Figueira-de-Lemos and Hadjikhani, 2014).

\subsection{Learning, trust-building and relationship commitment decisions}

The nature of a direct relationship with an existing partner firm drives the dynamic and cumulative processes of learning and trust-building and their subsequent relationship commitment decisions. Firms that have valuable network partners or existing relationships in the target market or with a target firm, gain privileged access to information about the market, the target firm and their business network. Market research may be unable to identify such privileged information that the firm has access to. Consequently, the firm enjoys insidership within its network (Johanson and Vahlne, 2009, p. 1423). It is supposed that firms that enjoy such an insidership position will have a tendency to increase their commitments or make a full acquisition. For example, studies have found support that firms increase their commitments or acquire partner firms as a result of explorative alliance learning (e.g. Yang et al., 2011).

When the existing or previous relationship with a target firm is that of a partial acquisition without an option to acquire fully, a firm willing to increase its commitment or equity stake can still acquire more through renegotiations with the target firm. If it is a publicly listed firm, this can be achieved by acquiring the remaining equity from the public market offerings. The firm's willingness to increase its equity stake in the target firm will result from trust and the positive outcome of learning and relationship building. Otherwise, the outcome will be one of decreasing commitments in the target firm. Building trust in business relationships takes time because it is not based on formal agreements but a shared history of at least minimal satisfactory joint business experience (Johanson and Vahlne, 2009, p. 1418). This explains why the increment in commitment decisions in acquisitions may take several years.

Learning from a previous relationship entails learning about the partner's/acquisition target's business, partner/target assets, culture, organizational processes and the external 
business environment. Such learning associated with a firm's prior acquisition experience has been shown to increase the likelihood that the firm will engage in subsequent international acquisitions (Collins et al., 2009).

Learning and knowledge development are also about the business environment. In the case of countries with different or unstable institutions like emerging economies, acquiring companies have to deal with unclear and changing rules (Santangelo and Meyer, 2011; Oguji and Owusu, 2017). Even in highly-developed countries with stable institutions like the USA and Sweden, new governments change tax policy or legislation on foreign investments, which foreign companies do not expect. Learning about local institutions (both formal and informal) is also vital for foreign subsidiary survival and increasing commitments. Knowledge about host country institutions enables the firms to lobby these institutions, develop capabilities for coping with or even benefiting from institutional pressures and to search for better alternatives on contractual terms in acquisition negotiations. In addition, learning about and influencing institutions can be done through partially acquired companies (Frynas and Mellahi, 2003; Oguji and Owusu, 2017).

\subsection{Conceptual framework}

Our integration of the Uppsala model and acquisition strategies is summarized in Figure 2. Based on the foregoing literature review, a firm's acquisition entry strategy can start through an existing or non-existing relationship with a target firm or acquisition of host country knowledge through the firm's market presence and ongoing business in a particular host country. Firms may acquire partially, which means that they buy only part of the target firm and have to compromise with other owners in decision making, or they may have the strategy of acquiring in stages, i.e. they intend to acquire more of the target firm as time goes on. Thus, their equity in the target firm could increase with time, but could also decrease if they decide to sell off part of their equity. Firms may also acquire fully at the beginning, or this may happen later in the relationship after staged acquisition.

State variables such as knowledge opportunities, host country knowledge and target-specific experience explain the current state of the relationship (Johanson and Vahlne, 2009). Change variables include the outcomes of the relationship, such as acquisition strategies. The levels of learning and trust-building also show the evolution of the relationship (Johanson and Vahlne, 2009). The firm's network position is made up of its valuable network partners or existing relationship with a target firm in a host country that provides the company privileged access to information about the market, its relationship partners and business network (Johanson and Vahlne, 2009).

The existing relationship between a parent MNE and a foreign target (e.g. distributor relationship, supplier-customer relationship, partial acquisition) builds the MNE

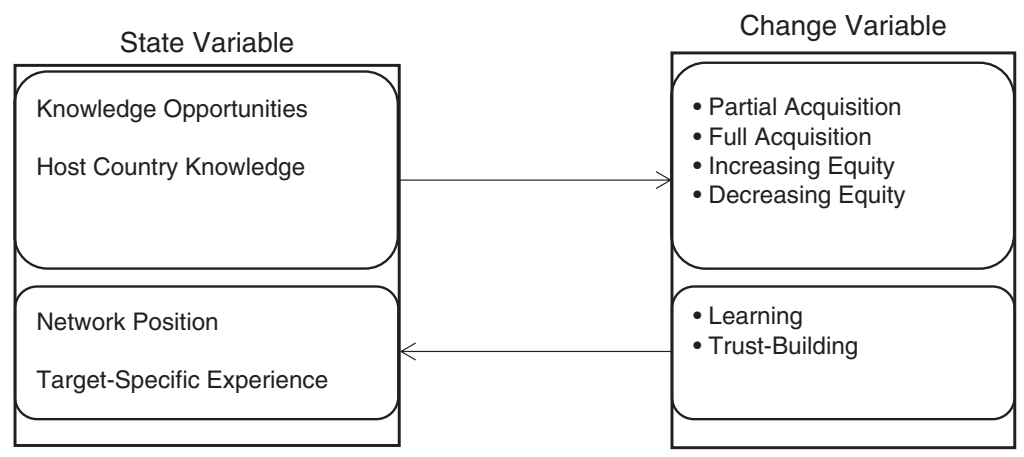

Finnish multinationals in foreign markets
Figure 2.

Conceptual framework: integration of Uppsala model and acquisition strategies 

into knowledge opportunities (Johanson and Vahlne, 2009) for which an acquisition by the parent MNE is an outcome. Through this acquisition and accumulation of knowledge about doing business in the host country, the firm's host country knowledge develops (Chen, 2008; Puck et al., 2009; Vahlne and Johanson, 2013) which in turn enables it to initiate the next commitment decisions such as increased equity or full acquisition. An increase (e.g. full acquisition) or decrease (e.g. market-exit or divestments) in equity stake depends on the outcomes of learning and trust-building. Increasing commitments enables the firm to effectively exploit local market opportunities (Johanson and Vahlne, 2009). Exploiting local market opportunities may also require subsequent full acquisition and can aim at developing new competencies or product market extension. Thus far, we assert that the basic dynamic of the Uppsala model fuels equity changes in acquisition due to the relationships that both parties build by learning and trust-building, which leads to new knowledge opportunities and further development of the relationships toward increasing equity or decreasing equity stake (or subsequent divestment). The following discussion will center on partial acquisition at the time of market entry as a precursor to changes in equity stake when the acquiring firm has to build trust, gain market and host country knowledge and, gain deeper knowledge of target firm assets.

MNEs without a previous relationship with a target firm may seek partial acquisition due to information asymmetry they face (Xu et al., 2010) as a result of differences in financial institutions that govern financial transparency and disclosure (Zhou et al., 2007) that makes assets valuation costly. Chen and Hennart (2004, p. 1128) argued that parent firms confronted with these challenges opt for partial acquisition as a means to build reciprocity or a "hostage" into acquisition contracts, something that the seller would want to avoid if the underlying assets of the firm are a "lemon."

Trust and commitment between the acquiring firm and the partially acquired target should be an antecedent to knowledge sharing and, thus, the performance of the alliance relationship (Yuliani and Vanessa, 2007). It is believed that increasing levels of trust or commitment to the relationship between the parent firm and partially acquired firm should enhance the tendency of the acquiring MNE to increase their equity commitments in the partially acquired targets. In contrast, the failure of both parties to develop mutual trust and commitment in their relationship may hinder knowledge sharing and knowledge opportunities. Thus, in the absence of knowledge opportunities or trust, parent MNEs will decrease their commitment to the target firm.

Empirical evidence suggests that MNEs that do not possess sufficient knowledge of the value of the target firm's assets and business are more likely to opt for partial acquisition at the time of market entry, especially in technology acquisitions (Folta and Miller, 2002). These studies argue that MNEs opt for partial acquisition to bide time and enable them to gain target-specific knowledge and market knowledge. During this period, the acquiring MNE becomes an insider, thereby allowing it to gather information on the target company, target technology and host country market. This gives it an information advantage over outsiders when subsequently buying out the target (Dapena and Fidalgo, 2003; Folta and Miller, 2002).

In addition to gaining knowledge about the target assets, partial acquisition also gives the parent MNE a means to gain institutional knowledge on how to deal with challenges arising from restrictive mergers and acquisition (M\&A) laws, non-transparent institutions, institutionalized corruption and political risks of host countries (Oguji and Owusu, 2017). Partial acquisition could also provide a platform for developing political strategies in host countries (Boddewyn and Brewer, 1994; Schuler, 1996) and for shaping government policy (Hillman, 2003).

In summary, using the Uppsala model to explore and analyze acquisition entry strategy provides us a framework for studying how acquisition strategy evolves from initial 
relationships through partial acquisition to full acquisition or divestment. The core of the framework is how target-specific experience and host country knowledge are transformed through learning and trust to expand knowledge opportunities and impact commitment decisions about the level of equity stake in acquisition and its expansion or reduction over a period of time.

\section{Research design}

\subsection{Case study research methodology}

For this study, a multiple case study research approach via abductive theory-building was chosen because it is the best way to explore the subject and contribute to theory in a situation where there are no pre-existing results to test with quantitative studies (Figueira-de-Lemos and Hadjikhani, 2014). In other words, our theoretical framework provides themes for data collection, analyzing the empirical data and relating our results to existing research and theories. The method of using extant theory in theory-building case study research is referred to as "systematic combining" (Dubois and Gadde, 2002) or "in vivo approach to theory-building" (Andersen and Kragh, 2010), and has been applied similarly to address criticism of the Uppsala model (Figueira-de-Lemos and Hadjikhani, 2014).

Furthermore, the multiple case study method allows us to investigate in-depth the determinants of equity changes in acquisitions within their empirical contexts (Yin, 2009). There is rather limited research on the determinants of equity changes in acquisitions. This makes it necessary for us to utilize a case study and qualitative research approach in order to explore in-depth the determinants of equity changes in acquisitions through the experiences of the informants triangulated with secondary data (Gummesson, 2006).

\subsection{Data collection and analysis}

Primary data were collected mainly using face-to-face interviews. We collected secondary data available from company web pages and other documentations from the case companies in addition to data on foreign acquisitions of Finnish companies from the FDI data bank of a Finnish University. The interviewees were acquisition managers (Vice President/Director M\&A) of the acquiring firm who were responsible for acquisition decisions during market entry and eventual changes in equity later on. Thus, the case firms are the level of analysis while the unit of analysis is the firm-specific acquisitions in foreign markets.

The cases were selected using theoretical sampling (Eisenhardt, 1989), i.e. we selected cases that would achieve adequate matching with the conceptual abstraction (Figueira-de-Lemos and Hadjikhani, 2014). We did this by identifying the key constructs for the study (see the conceptual framework, Figure 2) and purposively sampling cases from the FDI internal data bank of a Finnish University. Our cases have been chosen based on acquisitions made between 2000 and 2013 to ensure we could find the appropriate managers responsible for the acquisitions. We focused our search on Finnish manufacturing companies and a total of 13 suitable companies involving 41 cases of equity changes in partially acquired subsidiaries were initially identified. After contacting the managers, six case companies comprising of six cases of equity changes in acquired foreign subsidiaries agreed to participate in the interviews.

We selected Finnish investments because of the unique context of Finland as a small and open economy whose medium- and large-sized companies are dependent on IB for their growth. Finnish firms are highly internationalized, however, their relative smallness confers greater challenges in their foreign acquisitions compared to firms from large economies like the USA and Japan (Laanti et al., 2009). For these reasons, they very much fit the theoretical requirements of this study. The business sectors of the cases selected are manufacturing and services of elevators and cranes, paper, energy, purification processes, casting 
BJM

14,2

Table I.

Case companies and characteristics solutions, meat and poultry and food processing. Their market capitalization ranges from $€ 79 \mathrm{~m}$ to $€ 20 \mathrm{bn}$ (Bloomberg, 2015). The selected case companies, business sector, number of employees, number of subsidiaries and sales revenue for 2016 are shown in Table I.

The face-to-face interviews took place in 2015 and lasted for an average of 50-60 min each. A digital voice recorder was used to record and store the data to ensure dependability and repeatability. Our coding process or data reduction was done via within-case analysis through a cyclic process of axial coding, selective coding and open coding (Sobh and Perry, 2006, p. 1204) to capture emerging themes and relate to our conceptual framework. Our findings from the within-case analysis were organized into a meta-matrix table (Table II), which enabled cross-case analysis through a search for commonalities, comparison and generalizability (Welch et al., 2011, p. 745).

Ontological appropriateness was achieved by formulating the appropriate research question for qualitative research (Yin, 2009). Contingent validity was achieved via theoretical sampling as described in the case selection process above. Multiple perceptions of participants were achieved in three ways. First, we ensured the triangulation of interview data and secondary data sources to achieve consistency. For example, equity stake informed by the managers was triangulated with those reported in their website and press releases. Second, we ensured that there was consistency in transcription of the interview data by the three researchers (Patton, 2002). Third, we sent the transcribed interviews to the interviewees for verification (Patton, 2002). Methodological trustworthiness was achieved by the establishment of a case study database comprising of interview guide questions, a summary of the data collected from each case study (Tables II and III), and interviewee anonymity and confidentiality confirmation. Construct validity was ensured by using existing theory (i.e. internationalization process theory and literature review) which provided the constructs for this study.

\section{Results}

Table II shows mostly secondary data collected for each case acquisition such as host country of acquisition, equity stake at entry and during change, year of entry and year of equity change, parent's total sales in year of target acquisition and year of equity change, foreign sales in year of entry and year of equity change, target annual sales prior to acquisition, total FDI experience prior to target acquisition and after equity change, market growth and political risk situation of the target host country. From the secondary

\begin{tabular}{|c|c|c|c|c|c|}
\hline No. & Companies & Business sectors & $\begin{array}{l}\text { Number of } \\
\text { employees } \\
\text { (2016) }\end{array}$ & $\begin{array}{c}\text { Number of } \\
\text { subsidiaries } \\
\text { (2016) }\end{array}$ & $\begin{array}{l}\text { Sales } \\
\text { revenue } \\
(2016)\end{array}$ \\
\hline A & KONECRANES & $\begin{array}{l}\text { Manufacturing and Services: cranes for } \\
\text { shipbuilding, ports, automotive, waste to } \\
\text { energy and steel equipment }\end{array}$ & 10,950 & 42 & EUR 2.1bn \\
\hline B & ATRIA & $\begin{array}{l}\text { Manufacturing: meat and poultry } \\
\text { production, food processing, convenience } \\
\text { food business }\end{array}$ & 4,315 & 18 & EUR 1.35bn \\
\hline $\mathrm{C}$ & KONE & $\begin{array}{l}\text { Manufacturing and Services: elevators, } \\
\text { escalator and automatic building doors }\end{array}$ & 52,100 & 60 & EUR 8.8bn \\
\hline $\mathrm{D}$ & KEMIRA & $\begin{array}{l}\text { Manufacturing and Services: pulp and paper, } \\
\text { oil and gas, mining and water treatment }\end{array}$ & 4,818 & 43 & EUR 2.4bn \\
\hline $\mathrm{E}$ & COMPONENTA & $\begin{array}{l}\text { Manufacturing: design, engineering and } \\
\text { casting solutions }\end{array}$ & 4,500 & 5 & EUR 545m \\
\hline $\mathrm{F}$ & FAZER & $\begin{array}{l}\text { Manufacturing and Services: Food } \\
\text { processing and contract catering }\end{array}$ & 15,000 & 12 & EUR 1.6bn \\
\hline
\end{tabular}




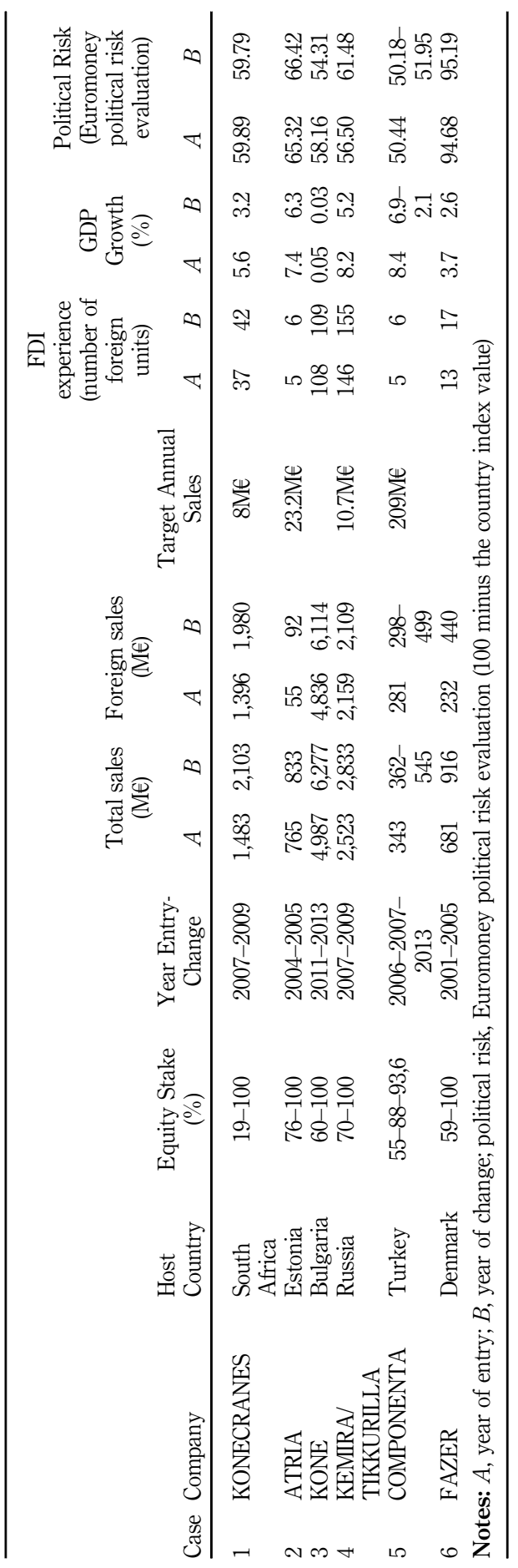

Finnish multinationals in foreign markets

277

Table II. Case study data matrix 
BJM
14,2

278

Table III.

Meta-matrix:

determinants of

equity changes

in acquisitions

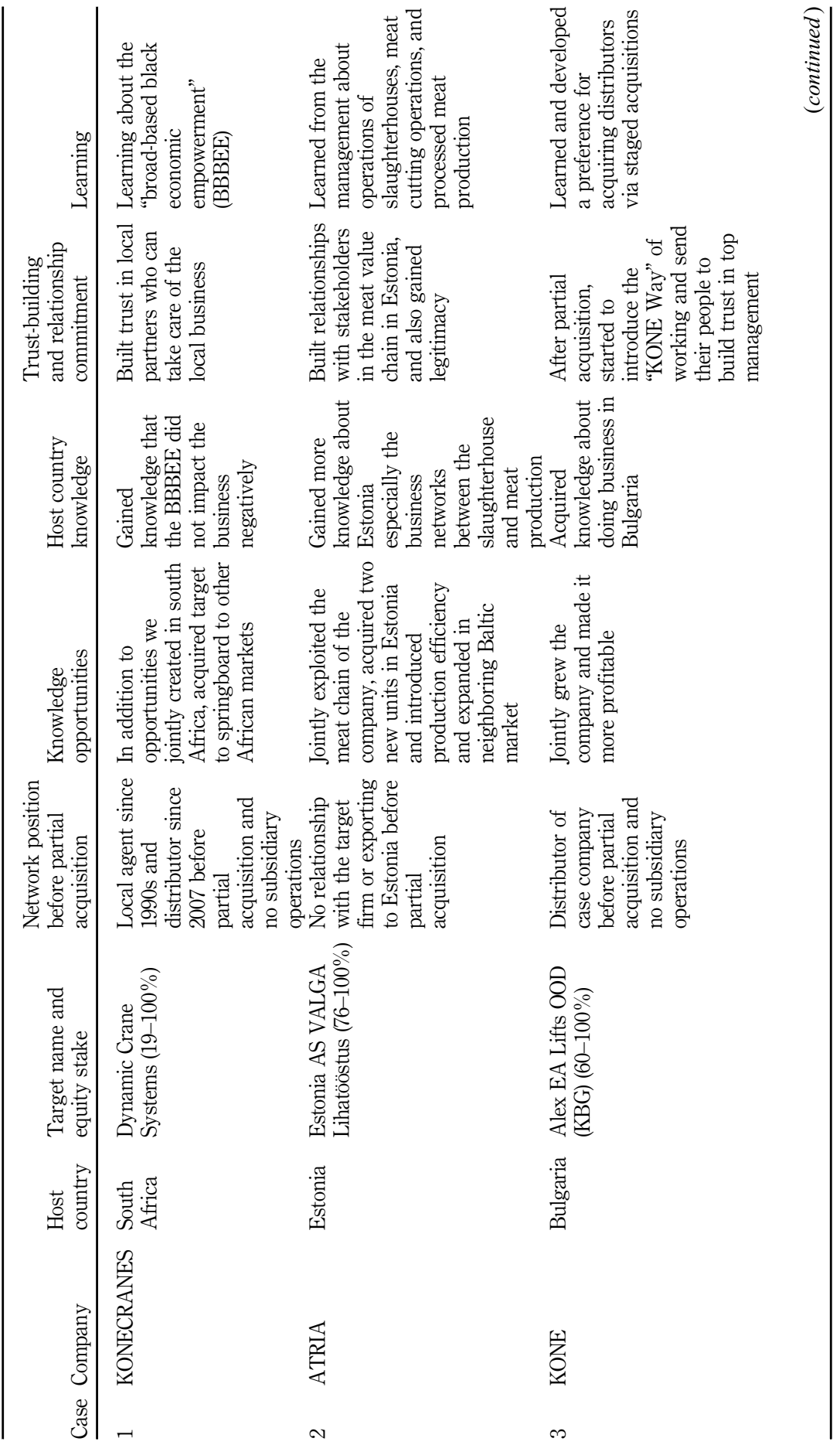




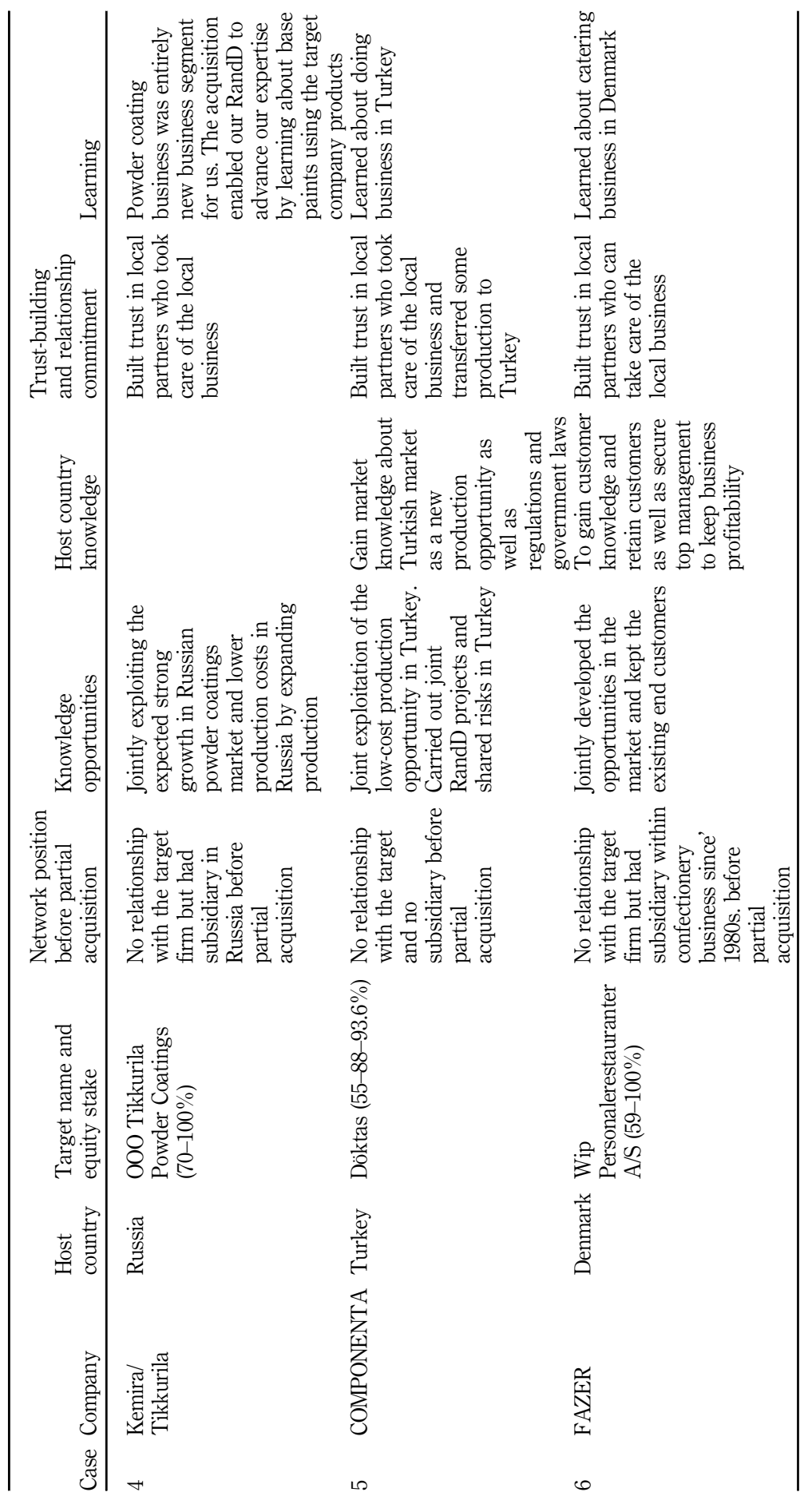

Finnish multinationals in foreign markets

279

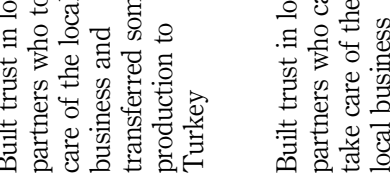

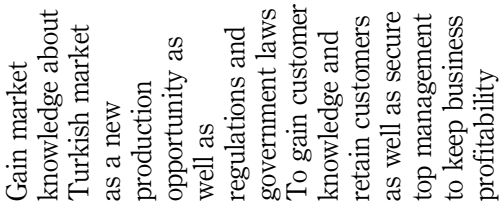

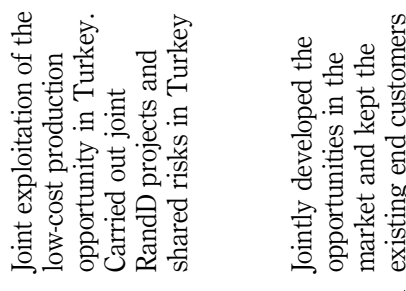

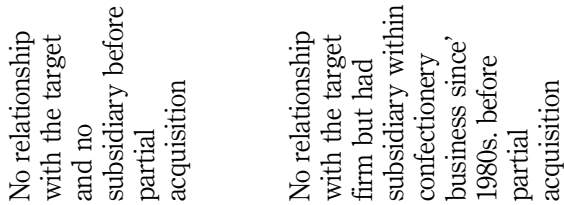
Table III. 
data, there were two cases of political risk decrease in the target host country and four cases of political risk increase in the target host country during the year of equity change. Moreover, there was a clear decrease in GDP growth rate for all the countries during the years of equity changes. However, total parent firm sales, and FDI experience were all higher during the years of equity changes. Although, there was a clear indication that cases 2 and 5 acquisitions were done in response to price competition due to the integration of the European market and entrance of emerging market multinationals, respectively, the other cases were driven primarily by market expansion (cases 1 and 3) and business segment expansion (cases 4 and 6). The secondary data points to the importance of sales growth and increased FDI experience prior to equity changes. Both total sales and profitability increased after the acquisition in all cases. More so, an increase in FDI experience occurred in all cases as we see its importance for example, in case 2, where the manager informed us about how the experiences from two new acquisitions in the same host country triggered the importance of increasing their equity stake in order to reap synergies.

In summary, while the secondary data can give an overview, it does not address the issue-specific reasons leading to the equity changes in partially acquired subsidiaries. Table III shows the equity changes from the case acquisitions and the summary descriptions of the findings related to these changes from the primary data.

\subsection{Findings and propositions}

Target-specific experience. Two cases (cases 1 and 3) had target-specific experience when they made partial acquisitions while four cases (cases 2, 4, 5 and 6) did not have target-specific experience prior to the partial acquisition. The acquired firm in case 1 had been a local agent of the acquirer since the 1990s and in 2007 became a distributor before partial acquisition in the same year. The acquired firm in case 3 was a distributor of the acquirer before partial acquisition. In both cases, the parent firm had none of its own subsidiary operations in the markets before the partial acquisitions. Clearly, target-specific experience had been gained prior to the partial acquisitions and lack of host country knowledge was the main reason for their preference for partial acquisitions at the time of market entry. Target-specific experience was expressed as "We knew the target, but we opted for partial acquisition because we did not know how the BBBEE legislations will affect how business is done in South Africa" (case 1). For case 3:

When they are core distributor, we get some operative financial information. We know the partner and we know exactly how many units they have sold and based on our visits we know what kind of operational quality they have. Thus, we have the information before starting to discuss about possible acquisition. (case company $\mathrm{C}$ )

Cases 2, 4, 5 and 6 did not have target-specific experience before the acquisition. In addition, Cases 2 and 5 did not have any subsidiary operations in the host country before the partial acquisition. These firms expressed the importance of target-specific experience via partial acquisition to gain knowledge about the partner and the true value of the partner's assets before making full acquisitions. For example, case 6 expressed that:

Often in negotiations the seller and buyer have a different opinion on the valuation. Staged acquisition is a good way to bridge the valuation differences. We compromise that we make some down payment, and the sellers keep minority. During this time, we get to know the actual worth of the business and then based on the performance in 2 or 3 years, we acquire the rest at predetermined amount. (case company F)

Even with exporting operations before the acquisition (e.g. case 2), a partial equity stake was still preferred during initial market entry. "We acquired in stages so that we can get more 
information about the partner and as soon as more information becomes available, we increase our equity to 100 percent."

Case 5 expressed that through partial acquisition, "We gain enough information and experience about the target, then basically we can form the final view either to exit by selling it or acquire the remaining stake from the other party."

Thus far, partial acquisition provides a platform for gaining more knowledge about the target firm and understanding the true value of the partners. The results imply that a positive experience of a partner should lead to an increasing equity stake while a negative experience from a partner should lead to a decreasing equity stake. Consequently, we propose the following proposition:

$P 1$. The acquisition of target-specific experience is a determinant of equity changes in partially acquired foreign subsidiaries.

Trust-building and relationship commitments. Relationship commitment was expressed via two perspectives. First, there were cases where the acquiring firm had a non-equity business relationship (e.g. agent, distributor) with the target firm before the initial acquisition, but made a partial acquisition and increased their equity afterward (cases 1 and 3). Second, there were cases where the primary relationship started from partial acquisition, and then they increased their commitments to higher equity stake or full acquisitions (cases 2, 4, 5 and 6).

Clearly these cases exhibit a pattern of relationship commitment where the state variable is either an existing relationship in the form of distributorship arrangement (case 3), local agent (case 1) or a partial equity (cases 2, 4, 5 and 6) of at least 55 percent. For case 5, they acquired partially and transferred some production to Turkey to take advantage of the low-cost production. When they gained more knowledge of the host country and acquired the target, they decided to make the next commitment decisions by acquiring more equity and moving more production to the Turkish factory because of increased manufacturing costs in Finland.

Several interviewed managers expressed the need for building trust as precursor of the next commitment decision or relationship commitment. "We wanted to have some local partners, whom we could trust and who can take care of the local business" (case 6). Based on the foregoing, we propose the following proposition:

$P 2$. Trust-building and relationship commitment are determinants of equity changes in partially acquired foreign subsidiaries.

Knowledge opportunities. The interview data points to several kinds of opportunities that were jointly created. For example, from the six cases, cases 1, 2, 3, 5 and 6 did not have knowledge of the host country when they acquired the target firm. They started with partial equity of at least 19 percent and increased their equity to at least 93.6 percent later on. The acquisition managers cited the lack of host country knowledge (market and institutional) when they initially entered the market. These acquisitions were made in South Africa, Estonia, Bulgaria, Turkey and Denmark.

Case company B described their acquisition in Estonia (case 2) as a stepwise approach toward majority stake. Before the acquisition, the case company had been exporting meat to Estonia. However, the exporting operation was not adequate to gain greater familiarity of the local competitors deep knowledge of the market, and legitimacy. In addition, the case company's market growth motives had compelled them to look for meat processing companies in Estonia in order to expand their processing capacity and achieve market growth. The acquired target had a market share of 15-20 percent in Estonia. The choice of staged acquisition was only "sort of a time issue to make down payment and get more knowledge about the host market conditions." Furthermore, the manager for case 2 informed us that they made two additional acquisitions in the same country in 2008 and integration of 

partially acquired unit with the recent acquisition required increasing their ownership stake. As a result, they acquired the remaining equity of the partially acquired unit.

According to case company $\mathrm{C}$, the main motive for the staged acquisition (case 3 ) was risk sharing when entering a new and unknown market and to gain market knowledge:

If you go to an unknown market or such market area where you have no access, basically it carries a big risk and you may want to share the risk for example with the local firm and then make a contract that after 3 or 5 years there are some option arrangements in which you can buy the remaining equity out from the acquisition. (case company $\mathrm{C}$ )

Case company $\mathrm{F}$ expressed the reason for the staged acquisition (case 6) with the following statement:

Our reasons for staged acquisition was that we were entering a new business segment that was owned by our competitors and we did not have market knowledge and we wanted to keep the existing management for continuous success of the company. In this type of business, customer retention matters a lot that is also why retaining local managers is of importance to the business. Prior to this acquisition we had no contract catering business in Denmark but had other subsidiaries within confectionery business since the 1980s. The target firm was owned mainly by the heirs of the founder and a small fraction by the management. We acquired first $59 \%$ from the heirs at fixed price (with customary representation and warranties). When we acquired market knowledge, we used call options to acquire the remaining stake after three years from the remaining owners. (case company F)

From the interview data, deficiency of host country market knowledge propelled the MNEs to utilize staged acquisition en route to full acquisition when entering these markets. The staged acquisition gave the parent firms time to acquire market knowledge and host country knowledge during a specified period. These firms increased their equity stake and made their final down payment after they had gained sufficient knowledge.

For case 3, even though they had target-specific experience before the acquisition, the interviewing manager reiterated that:

The partial acquisition was aimed to gain a foothold in the market, and to wait and gain knowledge of how the market will develop or when portions of the market will swings to global players. When this is the case, it is more significant from our company point of view to increase our equity stake to full acquisitions. (case company C)

Similarly, for case 1, it involved an acquisition in the South African market. Though they had target-specific experience, the deficiency of host country knowledge in terms of their inability to predict or interpret policies like the impact of the "Broad-Based Black Economic Empowerment" (BBBEE) legislation led to their decision for staged acquisition. The staged acquisition enabled them to study, learn and gain more knowledge of the legislation before making the remaining down payment.

Thus far, it is evident that these firms utilized partial acquisition to learn about the target market and kick-start the relationship with the target firm, which in turn formed part of the firm's network position. Through this partial acquisition, the acquiring MNEs gained experience about the target firms (target-firm experience), and developed knowledge about the host country which provided a platform (state variable) that led to the next commitment decision, i.e. increasing equity stake (change variable).

Furthermore, opportunity development was expressed in terms of jointly growing the company and increasing profitability, exploitation of partner's local permits, exploitation of partner's access to local customers, external opportunities and opportunity for low-cost production. For example, case 3 expressed these in the form of "If you join me to grow the company and make it more profitable, I will give you more money, I will keep you more 
motivated throughout the business." Case 6 involved an acquisition in the catering business. According to the interviewed manager, customer retention is essential for the success of the business. Acquiring the business does not automatically translate into securing the end customers. "We needed to retain the previous management to continue to work for the company so we can jointly develop the opportunities in the market and keep the existing end customers of the company."

Turkey opened up an entirely new business opportunity as a low-cost production country but was seen as risky in case 5 :

We did not have an existing partner in the host country or existing business operations there. We entered the Turkish market to look for a partner with whom we could exploit the new business opportunities as well as gain from the local partner in terms of permits that are needed, and access to local customers. (case company E)

The acquisition was a means to respond to price competition or reduce the risks arising from price competition by transferring production and products to Turkey.

Overall, the data show that jointly and successfully exploiting opportunities during partial acquisition increases the likelihood that the acquiring firms will complete the down payment and acquire the remaining stake in the acquired firm. Notably, these firms were increasingly learning and exploiting the business opportunity in the existence of trust. However, if there is no opportunity development, the acquiring firm may decide to terminate the partial acquisition and exit from the market. Based on the preceding, we propose that:

P3. The discovery, creation and exploitation of knowledge opportunities is a determinant of equity changes in partially acquired foreign subsidiaries.

Learning. Learning was an important concept the acquiring managers referred to during the interviews. For example, case company $\mathrm{C}$ (case 3) stated that with over 20 years of international acquisition experience, they learned and developed a preference for acquiring their distributors mostly via staged acquisitions:

Over the years, we have learned that staged acquisitions are more successful from our company point of view. We usually acquire our distributors, and during the distributorship arrangements, we get some operative financial information. Thus, we have the information before starting to discuss a possible acquisition. Over the years, we have learned that staged acquisition is better because we get to keep the owner to work for us for a period to know the market and the country and once we have been able to gain this knowledge and develop the operations, we acquire the firm fully and make it a frontline. (case company $\mathrm{C}$ )

The interviewed manager in case company A (case 1) expressed how they implemented stage acquisition to learn more about the impact of the broad-based black economic empowerment (BBBEE) legislation in South Africa:

We did not know how far the broad-based black economic empowerment (BBBEE) legislation will go and how it will affect our business and productivity. It was a risk avoidance strategy for us. We took $19 \%$ equity at the start and a staged acquisition so that we can learn more about the legislation. If the (BBBEE) had an impact on our business, it would then be easy to divest the $19 \%$. However, it did not, and we acquired the remaining stake after two years. (case company A)

Thus far, when organizations enter foreign markets via acquisition they not only learn about the business, market, local laws and institutions, but also add the lessons from the acquired company to the organization's stockpile of knowledge about the acquisition process which is then utilized for future acquisitions. Based on the foregoing, we propose the following proposition:

P4. The outcome of learning from partial acquisition is a determinant of equity changes in foreign acquisitions. 
BJM

14,2

284

Based on the findings and propositions of this study, we have developed a conceptual model of the determinants of equity changes in partially acquired subsidiaries using constructs from the Uppsala model, as shown in Figure 3. Our findings and propositions suggest that when an acquirer meets the set expectations (i.e. "positive experiences") from its partially acquired target (such as provision of market information, socio/political environment, market knowledge, mutual and shared objectives) there is the likelihood of increasing equity commitments. On the contrary, there could be decreasing equity commitments or divestments in the event of a negative experience with a partially acquired target. Furthermore, our figure shows that positive trust-building and relationship commitment are determinants of equity changes in a partially acquired subsidiary. This can be captured via evolving business relationships that the parent firm has had with the target firm from the period of non-equity relationships (e.g. distributorship, agents etc.) to equity relationships, or from lower equity commitments to higher equity commitments.

Figure 3 also shows that the ability of the parent firm and acquired target to jointly create and exploit knowledge opportunities is a determinant of increasing equity commitments. Knowledge opportunities involve finding and generating knowledge as well as applying knowledge to develop new opportunities. Finally, the outcome of learning from the partially acquired target about their business and host country institutions, determines the direction of equity changes. Learning is achieved through path dependence and wait-and-see strategies. In summary, Figure 3 provides the determinants based on the four sub-concepts of the Uppsala model.

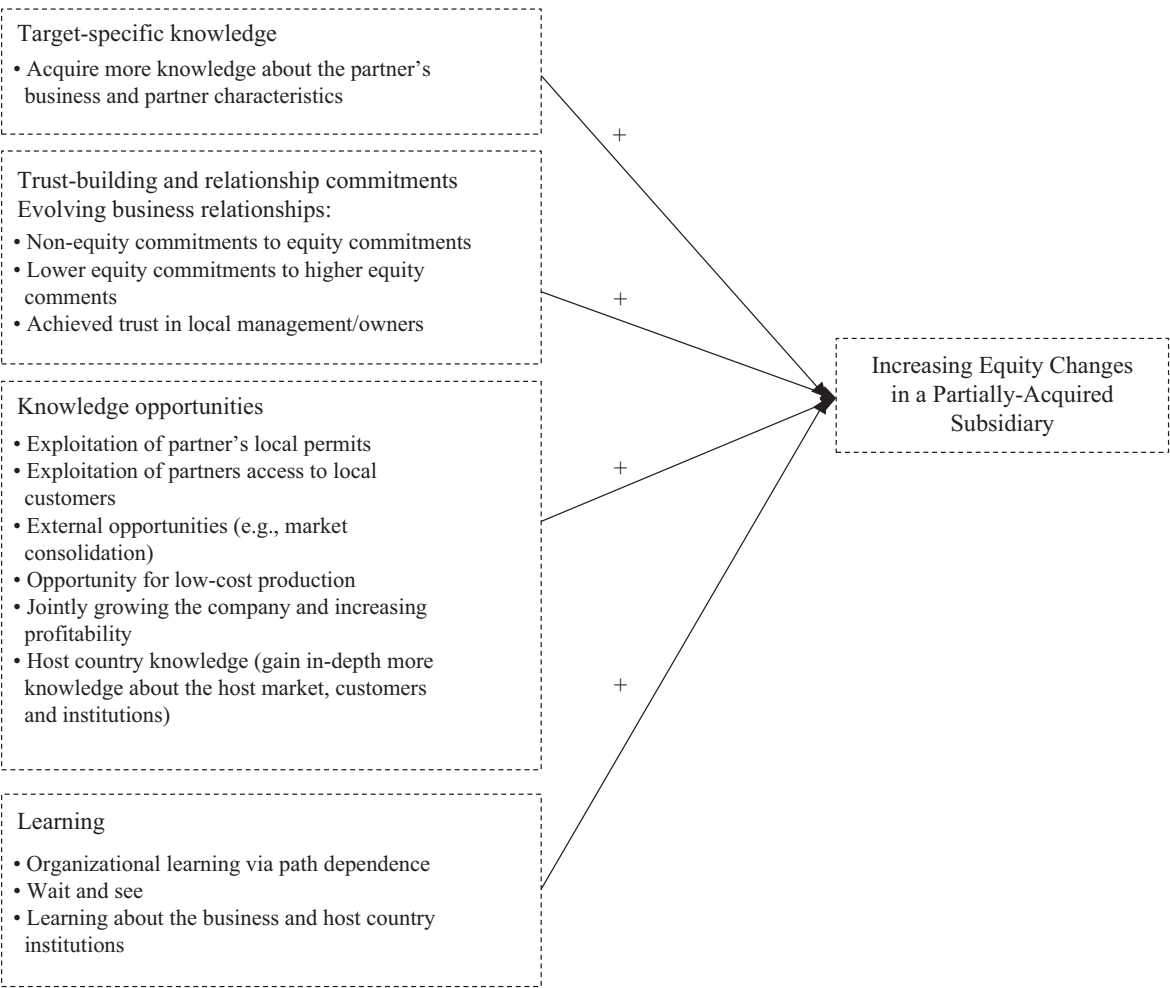

Figure 3.

Conceptual model of determinants of equity changes in partially acquired subsidiaries

\section{- Wait and see \\ - Learning about the business and host country} institutions 


\subsection{Theoretical and managerial implications}

This study makes several contributions to theory and research in post-market entry strategies in the context of international acquisitions. First, this study extends the application of the Uppsala model (Johanson and Vahlne, 1997, 2009; Vahlne and Johanson, 2017) to international acquisitions. This is one of the first study to apply the Uppsala model empirically to analyze international acquisitions. In contrast to the critics of the Uppsala model who state that it cannot be used to study acquisitions because they see acquisition as a one-time decision (Andersen, 1993; Oviatt and McDougall, 2005), our study shows that by viewing acquisition as a continuum of increasing and decreasing equity stake, it is possible to analyze it through the state and change variables in the Uppsala model. The Uppsala model explicitly shows how commitment decisions increase or decrease as a result of the acquisition of knowledge, trust and commitment of both the acquiring MNE and target firm. Thus, partial acquisition and staged acquisition can serve as foothold where parent firms can apply wait-and-see-strategy and both partners can learn about each other and build trust (Clarke and Liesch, 2017).

This study brings a process and behavioral approach to the study of acquisitions which has previously been mainly done using cross-sectional and quantitative methods together with economic theories with neoclassical assumptions (see Johanson and Vahlne, 1990 for a summary of the behavioral and economic internationalization models). Figure 4 shows the process of changes in equity stake in acquisitions.

This is a major contribution to the research on acquisitions. We open a new area of research that will enable researchers to delve into the processes and managerial interactions that occur during the process from partial acquisitions to full acquisitions or divestment. With increasing globalization and expansion of acquisitions to very different market contexts like Africa and Asia, these interactions and behavioral factors are likely to become more complex. Studying these factors will therefore improve our theories as well as managerial implications.

This study develops constructs to explain changes in equity stake in acquisitions. We showed that through learning and positive target-specific experience, firms do change their equity stake in partially acquired subsidiaries. We have also shown that trust-building and relationship commitment as well as the opportunity that develops and is jointly exploited during the relationship are determinants of equity changes in partially acquired subsidiaries. Additionally, we have provided specific determinants of equity changes in acquisition (Figure 3) and constructs of the four main concepts of the Uppsala model (Figure 4). These constructs, e.g., "non-equity commitments to equity commitments,"
State Variables

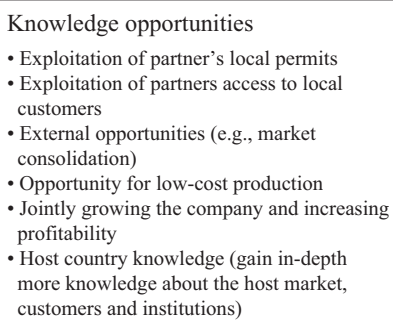

- Exploitation of partner's local permits

- Exploitation of partners access to local customers

- External opportunities (e.g., market consolidation)

- Opportunity for low-cost production

- Jointly growing the company and increasing

profitability

- Host country knowledge (gain in-depth

more knowledge about the host market, customers and institutions)

Target-specific knowledge

- Acquire more knowledge about the partner's

business and partner characteristics
Change Variables

- Partial Acquisition

- Full Acquisition

- Increasing Equity

- Decreasing Equity

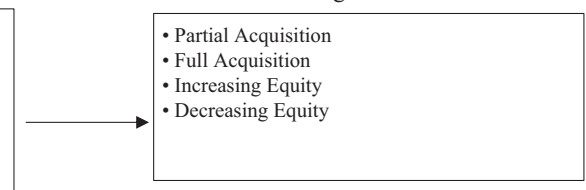

Learning

- Organizational learning via path

dependence

- Wait and see

- Learning about the business and host

country institutions

Trust-building and relationship

commitments

- Evolving business relationships

- Achieved trust in local management/owners
Finnish

multinationals in foreign markets

285
Figure 4.

Process of equity changes in acquisitions 
"lower equity commitments to higher equity commitments" (Figure 3), specify the main concepts and allow researchers to study them specifically and deepen our knowledge. They can be used for acquisition studies as well as other entry mode studies.

Our study contributes to studies on post-entry strategies of multinationals in foreign markets (see e.g. Benito et al., 2009; Puck et al., 2009; Ogasavara and Masiero, 2012) by extending the context to international acquisitions. We have shown that the decisions of firms at post-market entry are partly dependent on their knowledge and relationship liabilities at the time of market entry. Such liabilities are summarized as outsidership, foreignness (Johanson and Vahlne, 2009), "information deprivation liabilities" (Johanson and Vahlne, 1977) and deficiency in host country knowledge (Oguji and Owusu, 2017) leading to entry via partial acquisitions (Duarte and García-Canal, 2004; Oguji and Owusu, 2017). Consequently, their ability to overcome these liabilities through acquisition of knowledge (Johanson and Vahlne, 2009), target-specific experience (Oguji and Owusu, 2017) and learning and capabilities (Wei and Clegg, 2015), determines their post-market entry commitment decisions.

Our results provide managers of partially acquiring companies knowledge of the importance of a strategy for trust-building, and opportunity development in order to learn more about the partner, the business networks and the business environment which enables them to make informed decisions about increasing or decreasing their equity. The relationship and networking approach of the framework is a different approach to business strategy that a large amount of research has shown to be essential for business in most non-western markets (Jansson et al., 2007). Therefore, this study gives managers a new tool for their internationalization process. Furthermore, while host country institutional environment may increase the importance of partial acquisition and target-specific experience (relationship-specific knowledge) at the time of market entry (Oguji and Owusu, 2017), our framework offers managers a tool for actualizing their intended strategies later, after learning and developing the capabilities needed to change their equity stake. Finally, managers should not see acquisition as a one-time event but rather "a series of interconnected 'decision situations' that represents continual 'adjustments to changing conditions of the firm and its environment'" (Johanson and Vahlne, 1977, p. 26). Managers should view acquisition as a process that requires setting up necessary tools, structures and networks for learning, recognizing and jointly creating opportunities with the partially acquired targets. By acquiring partially at market entry, managers can apply a wait-and-see strategy (Clarke and Liesch, 2017) and thus, are better prepared to minimize uncertainty of outsidership and foreignness (Johanson and Vahlne, 2009) and "information deprivation liabilities" (Johanson and Vahlne, 1977; Wei and Clegg, 2015), and also identify new market opportunities (Johanson and Vahlne, 2009).

\section{Conclusion}

The goal of this study was to understand the determinants of equity changes in acquired foreign subsidiaries. We developed a conceptual model integrating acquisition literature with the Uppsala internationalization model which we used to operationalize the study and provide themes for analyzing data from qualitative studies of six cases from six Finnish multinational companies. The data were from both primary and secondary sources. We analyzed the data using systematic within-case and cross-case analysis through data reduction and coding processes based on the themes from our conceptual framework. Our results have enabled us to make four propositions that extend the knowledge of the determinants of equity changes in partial acquisitions. We have also provided constructs to operationalize the four concepts from the Uppsala model.

Our results show that learning, network position (target-specific experience), trust-building, relationship commitment and opportunity development lead to changes 
in equity in acquired foreign subsidiaries. However, our findings are limited in various ways. First, by focusing our study on acquisitions, we have omitted the detailed chain and continuum of events and relationships before an acquisition was made. To our defense, we do not claim that learning and relationship commitment begin from partial acquisitions, rather that partial equity stake provides stronger network ties through which the parent firm gets to know the target more for further opportunity recognition and exploitation, which in turn leads to increasing equity stake and thus strengthens the network position. Second, while the number of cases and our sampling procedures enable us to analytically generalize our results, they are limited by the fact that all the companies are from Finland. Third, our methodology does not allow us to statistically ascertain the degree to which these variables lead to equity changes. Consequently, in order to statistically ascertain the degree of these constructs, future researchers should utilize quantitative methodology on larger samples of specific industries to test and validate our propositions in different industries. Fourth, this study only accounts for the acquiring firm's perspective of the determinants of equity changes. Studies have suggested the importance of the target firm perspective in IB scholarship (Meglio and Risberg, 2010). As a result, we call for future studies to integrate target firm perspectives to gain a coprehensive view of the determinants of equity changes in acquired foreign subsidiaries. Fifth, our conceptual model allows us to focus on the behavioral approach and, thus, the firm as the unit of analysis. However, it has been shown that there are other surrounding processes, i.e. market or network internationalization, industry internationalization (Johanson and Vahlne, 1990, p. 22), or external institutional environment (e.g. Peng, 2002) that may be focused on by future researchers. Sixth, Santangelo and Meyer (2011) have shown that the processes of learning, opportunity creation and trust-building are moderated by institutional influences. Consequently, we call for future research to integrate the Uppsala model and institutional-based view of IB to uncover the degree to which institutional environments moderate the process of learning, opportunity creation and trust-building in the context of equity changes in partially acquired subsidiaries. Finally, four out of the six cases were the first FDIs/acquisitions of the case companies in the target countries. There is an opportunity for future studies to explore if the results of this study are applicable to equity changes in subsequent partial acquisitions of new targets in the same host country.

\section{References}

Andersen, O. (1993), "On the internationalization process of Finns: a critical analysis", Journal of International Business Studies, Vol. 24 No. 2, pp. 209-231.

Andersen, P.H. and Kragh, H. (2010), "Sense and sensibility: two approaches for using existing theory in theory-building qualitative research", Industrial Marketing Management, Vol. 39 No. 1, pp. 49-55.

Andersson, U., Johanson, J. and Vahlne, J.-E. (1997), "Organic acquisitions in the internationalization process of the business firm”, Management International Review, Vol. 37 No. 2, pp. 67-86.

Benito, G.R.G., Petersen, B. and Welch, L.S. (2009), "Towards more realistic conceptualizations of foreign operation modes", Journal of International Business Studies, Vol. 40 No. 9, pp. 1455-1470.

Bloomberg (2015), "Helsinki stock exchange", available at: www.bloomberg.com/quote/KNEBV:FH (accessed February 4, 2015).

Boddewyn, J. and Brewer, T. (1994), "International business political behavior: new theoretical directions", Academy of Management Review, Vol. 19 No. 1, pp. 119-143.

Brouthers, K.D. and Dikova, D. (2010), "Acquisitions and real options: the greenfield alternative", Journal of Management Studies, Vol. 47 No. 6, pp. 1048-1071. 
Chen, S.F. (2008), "The motives for international acquisitions: capability procurements, strategic considerations, and the role of ownership structures", Journal of International Business Studies, Vol. 39 No. 3, pp. 454-471.

Chen, S.F. and Hennart, J.F. (2004), "A hostage theory of joint ventures: why do Japanese investors choose partial over full acquisitions to enter the United States?", Journal of Business Research, Vol. 57 No. 10, pp. 1126-1134.

Clarke, J.E. and Liesch, P.W. (2017), "Wait-and-see strategy: risk management in the internationalization process model”, Journal of International Business Studies, Vol. 48 No. 8, pp. 923-940.

Collins, J.D., Holcomb, T.R., Certo, S.T., Hitt, M.A. and Lester, R.H. (2009), "Learning by doing: cross-border mergers and acquisitions", Journal of Business Research, Vol. 62 No. 12, pp. 1329-1334.

Contractor, F.J., Lahiri, S., Elango, B. and Kundu, S.K. (2014), "Institutional, cultural and industry related determinants of ownership choices in emerging market FDI acquisitions", International Business Review, Vol. 23 No. 5, pp. 931-941.

Dapena, J.P. and Fidalgo, S. (2003), "A real options approach to tender offers and acquisitions processes", CEMA Working Papers, Universidad del CEMA, Buenos Aires, February.

Das, T.K. and Teng, B.-S. (2000), “A resource-based theory of strategic alliances”, Journal of Management, Vol. 26 No. 1, pp. 31-61.

Duarte, L.C. and García-Canal, E. (2004), "The choice between joint ventures and acquisitions in foreign direct investment: the role of partial acquisitions and accrued experience", Thunderbird International Business Review, Vol. 46 No. 1, pp. 39-58.

Dubois, A. and Gadde, L.E. (2002), "Systematic combining: an abductive approach to case Research", Journal of Business Research, Vol. 55 No. 7, pp. 553-560.

Eisenhardt, K.M. (1989), "Building theories from case study research", The Academy of Management Review, Vol. 14 No. 4, pp. 532-550.

Figueira-de-Lemos, F. and Hadjikhani, A. (2014), "Internationalization processes in stable and unstable market conditions: towards a model of commitment decisions in dynamic environments", Journal of World Business, Vol. 49 No. 3, pp. 332-349.

Folta, T.B. and Miller, K.D. (2002), "Real options in equity partnerships", Strategic Management Journal, Vol. 23 No. 1, pp. 77-88.

Frynas, J.G. and Mellahi, K. (2003), "Political risks as firm-specific (dis)advantages: evidence on transnational oil firms in Nigeria", Thunderbird International Business Review, Vol. 45 No. 5, pp. 541-565.

Gummesson, E. (2006), "Qualitative research in management: addressing complexity, context and persona”, Management Decision, Vol. 44 No. 2, pp. 167-179.

Hennart, J.F. and Reddy, S. (1997), "The choice between mergers/acquisitions and joint ventures: the case of Japanese investors in the United States", Strategic Management Journal, Vol. 18 No. 1, pp. 1-12.

Hillman, A.J. (2003), "Determinants of political strategies in US multinationals", Business and Society, Vol. 42 No. 4, pp. 445-484.

Holland, W. and Salama, A. (2010), "Organizational learning through international M\&A integration strategies”, The Learning Organization, Vol. 17 No. 3, pp. 268-283.

Holm, D.B., Johanson, M. and Kao, P.T. (2015), "From outsider to insider: opportunity development in foreign market network", Journal of International Entrepreneurship, Vol. 13 No. 3, pp. 337-359.

Jansson, H., Johanson, M. and Ramström, J. (2007), "Institutions and business networks: a comparative analysis of the Chinese, Russian, and West European markets", Industrial Marketing Management, Vol. 36 No. 7, pp. 955-967. 
Johanson, J. and Vahlne, J.-E. (1977), "The Internationalization process of the firm - a model of knowledge development and increasing foreign market commitments", Journal of International Business Studies, Vol. 8 No. 1, pp. 23-31.

Johanson, J. and Vahlne, J.E. (1990), "The mechanism of internationalisation”, International Marketing Review, Vol. 7 No. 4, pp. 11-24.

Johanson, J. and Vahlne, J.E. (2009), “The Uppsala Internationalization process model revisited: from Liability of Foreignness to Liability of outsidership", Journal of International Business Studies, Vol. 40 No. 9, pp. 1411-1431.

Laanti, R., McDougall, F. and Baume, G. (2009), "How well do traditional theories explain the internationalization of service MNEs from small and open economies? Case: national telecommunication companies", Management International Review, Vol. 49 No. 1, pp. 121-144.

Lin, Z.J., Peng, M.W., Yang, H. and Sun, S.L. (2009), "How do networks and learning drive M\&As? An institutional comparison between China and The United States", Strategic Management Journal, Vol. 30 No. 10, pp. 1113-1132.

Magnusson, P. (2007), "An institutional perspective on initial subsidiary structure and subsequent change in multinational enterprises", ProQuest, Dissertation, Saint Louis University, Missouri, pp. 1-116.

Meglio, O. and Risberg, A. (2010), "Mergers and acquisitions-time for a methodological Rejuvenation of the field", Scandinavian Journal of Management, Vol. 26 No. 1, pp. 87-95.

Meyer, K.E. and Tran, Y.Th. (2006), "Market penetration and acquisition strategies for emerging economies", Long Range Planning, Vol. 39 No. 2, pp. 177-197.

Öberg, C. (2014), "Customer relationship challenges following international acquisitions", International Marketing Review, Vol. 31 No. 3, pp. 259-282.

Ogasavara, M.H. and Masiero, G. (2012), "Entry mode and parent control: the impact of equity ownership changes on the longevity of Japanese FDI in Brazil", International Journal of Management, Vol. 29 No. 1, pp. 143-157.

Oguji, N. and Owusu, R. (2017), "Acquisitions entry strategies in Africa: the role of institutions, target-specific experience, and host-country capabilities: the case acquisitions of finnish multinationals in Africa”, Thunderbird International Business Review, Vol. 59 No. 2, pp. 209-225.

Oviatt, B.M. and McDougall, P.P. (2005), "Toward a theory of international new ventures", Journal of International Business Studies, Vol. 36 No. 1, pp. 29-41.

Patton, M.Q. (2002), Qualitative Research and Evaluation Methods, Sage, Thousand Oaks, CA.

Peng, M. (2002), "Towards an institution-based view of business strategy", Asia Pacific Journal of Management, Vol. 19 Nos 2/3, pp. 251-266.

Puck, J.F., Holtbru, D. and Mohr, A. (2009), "Beyond entry mode choice: explaining the conversion of joint ventures into wholly owned subsidiaries in the People's Republic of China”, Journal of International Business Studies, Vol. 40 No. 3, pp. 388-404.

Putzhammer, M., Fainshmidt, S., Puck, J. and Slangen, A. (2018), "To elevate or to duplicate? Experiential learning, host-country institutions, and MNE post-entry commitment increase", Journal of World Business, Vol. 53 No. 4, pp. 568-580.

Santangelo, G.D. and Meyer, K. (2011), "Extending the internationalization process model: increase and decreases of MNE commitment in emerging economies", Journal of International Business Studies, Vol. 42 No. 7, pp. 894-909.

Schuler, D. (1996), "Corporate political strategy and foreign competition: the case of the steel industry", Academy of Management Journal, Vol. 39 No. 3, pp. 720-737.

Shahrur, H. (2005), "Industry structure and horizontal takeovers: analysis of wealth effects of rivals, suppliers, and corporate customers", Journal of Financial Economics, Vol. 76 No. 1, pp. 61-98.

Sobh, R. and Perry, C. (2006), "Research design and data analysis in realism research", European Journal of Marketing, Vol. 40 Nos 11/12, pp. 1194-1209. 
Song, S. and Zeng, Y. (2015), "Performance, partner relationship, and ownership change in international joint ventures: the case of Korean firms in Asia”, Journal of Asia-Pacific Business, Vol. 16 No. 3, pp. 171-190.

UNCTAD (2015), "World investment report 2015: value of cross-border M\&A sales, by sector/industry, 1990-2014", available at: http://unctad.org/en/pages/PublicationWebflyer.aspx?publicationid= 1245 (accessed November 26, 2016).

Vahlne, J.-E. and Johanson, J. (2013), "The Uppsala model on evolution of the multinational business enterprise-from internalization to coordination of networks", International Marketing Review, Vol. 30 No. 3, pp. 189-210.

Vahlne, J.E. and Johanson, J. (2017), "From internationalization to evolution: The Uppsala model at 40 years”, Journal of International Business Studies, Vol. 48 No. 9, pp. 1087-1102.

Wei, T. and Clegg, J. (2015), "Overcoming the liability of foreignness in internationalization in emerging economies: lessons from acquiring a Chinese firm”, Thunderbird International Business Review, Vol. 57 No. 2, pp. 103-117.

Welch, C., Piekkari, R., Plakoyiannaki, E. and Paavilainen-Möntymäki, E. (2011), “Theorizing from case studies: towards a pluralist future for international business research", Journal of International Business Studies, Vol. 42 No. 5, pp. 740-762.

Xu, D., Zhou, C. and Phan, P.H. (2010), "A real options perspective on sequential acquisitions in China”, Journal of International Business Studies, Vol. 41 No. 1, pp. 166-174.

Yang, H., Lin, Z.J. and Peng, M.W. (2011), "Behind acquisitions of alliance partners: exploratory learning and network embeddedness", Academy of Management Journal, Vol. 54 No. 5, pp. 1069-1080.

Yin, R.K. (2009), Case Study Research: Design and Methods, 4th ed., Sage Publications, Thousand Oaks, CA.

Yuliani, S. and Vanessa, R. (2007), "A theoretical framework of alliance performance: the role of trust, social capital and knowledge development”, Journal of Management and Organization, Vol. 13 No. 1, pp. 4-23.

Zhou, J.Q., Anand, J. and Yu, J.J. (2007), "Information asymmetry in international acquisitions: the role of information institutions", Academy of Manage Proceedings, Vol. 1 No. 1, pp. 1-6.

\section{Corresponding author}

Nnamdi Oguji can be contacted at: nnamdi.oguji@gmail.com

For instructions on how to order reprints of this article, please visit our website: 